\title{
THE EPISTLE TO THE HEBREWS.
}

\author{
II. Chapters vii-x. 18.
}

BY W. T. WHITLEY, M. A., LL. D., PRESTON, ENGLAND.

With chapter seven we enter on the main theme of the epistle, the Priesthood of Jesus. After the many hints and the cautious preparation for it, less than a third of the space is spent on proving it. Direct and continuous exhortation follows from the middle of the tenth chapter, which will occupy our attention another time, with its modern application.

The theme met difficulties certain to be felt by most Jews. They were deeply attached to the sacrificial system descended from antiquity. It is therefore shown to be essentially prophetic, valuable not for itself, but for its hints of a deeper reality now presented in Jesus. No advantage is taken of the unworthiness of recent high priests, such as Annas or Caiaphas; the system is taken at its best in the person of Aaron; the sordid realities and reeking shambles of Jerusalem are not held up to disgust, but the ideal directions of Leviticus are chosen. These at their very best are shown to be inadequate. And was the system antique? yet it originated long after Abraham, who met a priest of an older and better type; and when it did come, it was only copied from a heavenly pattern, now presented not to Moses alone, but to all in the person of Jesus; the second-hand system must be abandoned for the first-hand.

There are three steps in the argument: First, that Jesus is a Priest, then that Aaron's high priesthood was only temporary and prophetic, then that Jesus is the High Priest prefigured, doing in reality what Aaron only excited hopes of. These points are then summed up. The 
turns in the argument are at viii. 1 , ix. $11, x .1$. It may be thus represented:

JESUS IS A PRIEST.

"Consider Melchizedek, the strange figure once in contact with our father Abraham. Not king alone was he, but priest also. As priest he blessed Abraham and received a tenth of his spoil. Of descent, of inauguration, of resignation, we know nothing; he is like the Son of God declared in the psalm to be priest. Such priesthood is permanent.

"Contrast him with the Levitical priests in the matter of the tithe. They tithe by law, he by merit. They tithe only their brethren, he the patriarch himself-yes, and bestowed on him a blessing also. They are dying off constantly, he is spoken of as living. Indeed as they were latent in Abraham, they themselves paid tithe to Melchizedek.

"See how inadequate is the Levitical priesthood. After many centuries' trial, its failure was declared in the promise that a different priest should be appointed after the order of Melchizedek. With this downfall of the priesthood comes the downfall of the whole Law. For observe the facts about the hero of the psalm, Jesus. He belongs to Judah, not Levi, and yet is priest; how about the Law there? Look at the promise in the psalm; our Priest is installed not by an arbitrary rule of hereditary descent, but by the inherent value of an indestructible life: 'After the order of Melchizedek.' This utterance repeals the former rule as to the priesthood as feeble and unhelpful-for the whole law was no real help-and substitutes a better hope which does bring us near to God.

"And this priesthood of Jesus was inaugurated with an oath, for 'the Lord swore;' whereas the Levitical priests had no such solemn appointment. This again guarantees us a covenant that is better.

"These priests have become numerous as death carries 
off one after another, but Jesus as He abides 'forever' has His priesthood changeless. Herein again $\mathrm{He}$ can thoroughly save those who approach God through Him, as $\mathrm{Fle}$ is still alive to intercede for them.

"How suitable is such a High Priest for us? Sundered from sinful men and exalted above the heavens, He need not, like those high priests, offer constant sacrifices; this He did once for all when He offered Himself. And thus, instead of an arbitrary succession of weak men, there is the Son of God, installed by His oath, consecrated forever.

AARON'S HIGH PRIESTHOOD WAS ONLY SECONDARY.

"Next to advance a step and crown this result. Of what stamp is our High Priest? He is seated on the right of the heavenly throne, minister of the Holy Place and of the original tabernacle pitched by God, not by man.

"High Priests exist to offer gifts and sacrifices; what has our High Priest to offer? The Levitical priests on earth offer their legal sacrifices; but they serve what is a mere copy and imitation of the heavenly realities, as Moses was warned when he was told to construct the Levitical tabernacle: 'Mind and make them after the pattern shown thee in the mount.'

"Consider the whole covenant with which the Levitical priesthood is bound up. How far better is that covenant which Jesus negotiated, based as it is on better promises. For if that covenant at Sinai had been faultless, there would be no room for a second; whereas God did find it faulty and say: 'The time is coming when I will make a new covenant with Israel.' When God uttered that phrase, a new covenant, He branded the other as old. But what was becoming old and growing obsolete even in the days of Jeremiah, is not far off destruction.

"Now even that first covenant had rites divinely appointed, and its sanctuary, ornamental in a way. For there was a tent piepared, in two parts, full of emblematic 
furniture which there is no time to expound in detail. Attend to the significance of there being two parts. Into the outer tent the priests may go freely, performing their duties; but into the inner tent may pass the High Priest alone, and he only once a year, after sacrifice. This is the divine meaning, that while the outer tent stands, there is for a sinner no way into God's presence. This symbol receives its explanation at this present time. And it is only as symbols that Levitical gifts and sacrifices are ofiered; they cannot help the conscience of a worshiper for they, like the food and drink and the various baths of the Levitical law, are rites affecting merely the flesh, imposed until a time when all should be set right in reality.

THE HIGH PRIESTHOOD OF JESUS IS REAL AND EFFECTIVE.

"Contrast the work of Christ, who ascended to usher in the new age. The blessings He offers come by means of the real original tabernacle, not the manufactured imitation; He depended not on the blood of the dumb goats and calves, but on His own blood; He entered once for all into the true Holy Place, obtaining thereby a redemption that is eternal. For if animal blood and ashes sprinkled on a man set him apart technically so far as his body is concerned, how much more shall the blood of Christ, who deliberately offered Himself to God, sinless, cleanse our conscience from lifelessness and enable us to serve the living God?

"His death has a double reference. Not only did it ratify a new covenant, but it redeemed those who transgressed the old covenant, and enabled them to enjoy the inheritance promised to Abraham. For a covenant involves the death of him who breaks it, as is represented in the actual death of the victims at the sacrifice which ratifies the covenant. But the death incurred by the general breach of the old covenant was borne by Jesus.

"That old covenant, important as it was, was inaugurated merely with blood. For Moses took the blood of calves and goats, and sprinkled both the book recording 
the covenant, and the people, and the tent, and all the utensils for the ritual. Indeed I may almost say that everything is cleansed in blood according to the Law. And if without shedding of blood no forgiveness is granted, these earthly copies of the heavenly tabernacle must be cleansed-in blood. Cleansed, in blood!

"But the real cleansing of the heavenly original must be with better sacrifices. For Christ did not enter an imitation holy place, but the very heavens, where He now represents us before God. Nor does He keep on offering Himself, as the earthly priest goes yearly into the holy place, with blood, and that not his own! Once only, at the crisis of the ages, has He manifested Himself to abolish sin by a real sacrifice of Himself. He is like us in death and judgment; but His death was to bear the sins of many, though Himself sinless; and sin being done with, the judgment is an award of triumph, namely that He may come again and complete the salvation of those who earnestly expect Him.

"Or look at the sacrifices. The Law simply foreshadowed the blessings to come, but did not pretend to bestow them; the priests cannot free worshippers from sin by those sacrifices which they keep on endlessly offering. For if the worshippers ever attained an easy conscience by a real cleansing, the round of sacrifice might cease, whereas it continues year after year reviving the recollection of sins without removing them.

"The fact is that no amount of bloodshed can take away sin; material acts cannot rectify spiritual wrong. And so when the Word became flesh, He took as His motto the old psalm which on the one hand declared that God wanted no sacrifice or burnt-offering, and on the other announced, 'I am come to do Thy will, O God.' Sacrifice, ordered indeed in the Law, is yet abolished, and obedience is exalted. Jesus never slew and offered a beast on the altar, throughout His life He obeyed God. And God accepting that obedience which culminated on the cross, willed to pronounce us thenceforth free from sin. 
"Those Levitical priests toil away at their useless drudgery, while our Priest is content with His one effectual life and death, and now confidently awaits in glorious rest the final issue of His work. For brief as was His career, it suffices thoroughly to make and keep men right with God. Have we not a clear promise of this? When Jeremiah was commissioned to announce the New Covenant, it proved to consist not simply in touching the hearts and consciences of men, but also in blotting out from God's mind the memory of sin. And since this is so, further sacrifice can only recall sin again to mind, and undo the work of Christ."

Perhaps the best way to study this great argument is not to follow it point by point, but to examine its teaching on four great topics: Covenant, Law, Sacrifice of Christ, Priesthood of Christ.

\section{COVENANT OR TESTAMENT; CONTRACT OR WILL?}

That a covenant was in question was almost hidden from the reader of the Authorized Version by the wrong translation Testament. Now in the Revised Version the true translation is given in such places as vii. 22, viii. 6-13, ix. 1-15, 18-20, x. 16. But right in the middle of a connected argument the $R V$ breaks it up and makes it illogical by keeping the old rendering for two verses. It may seem plausible to say that the only document which first comes into force at the death of him who made it, is a Will; but this shirks two points: There is nothing to limit our consideration to a document; the argument before and after is about a Contract, not a Will. Moreover the Jewish Law did not admit of wills; property was divided between the children with a double share to the oldest. If it be said (without much evidence) that wills had been introduced under Roman influence, the answer is plain, that a Roman will did come into force when made, before the death of the maker. Besides, who is the "Mediator" of a will, the Executor or Trustee? And 
who is supposed to die that the will may come into force? Christ? Then He willed away His gifts to others and was left destitute, which is absurd. The Father, so that Christ is joint-heir? The idea is unthinkable.

Trying then if the author is not more logical than the revisers think, we have as a literal translation of ix. 16-17: "For where there is a covenant, there must necessarily be borne the death of the covenanter. For a covenant is valid over dead (victims), since is it then of force in case the covenanter lives?" The translation is easy enough, but the question staggers a modern reader. This is only because we are more familiar with contracts signed, sealed and delivered, than with ancient Jewish covenants. These were usually ratified by a sacrifice, as we see in the cases of Abraham and Jacob, Genesis xv., xxxi. The meaning of this seems to be that each covenanter invoked on himself in case he broke his word, such a death as the victims actually bore. Now on this understanding the question in the epistle is most pertinent. The men who made the first covenant broke it and incurred the penalty of death; but Christ bore that penalty and so redeemed their transgressions, leaving them pardoned and able to benefit by the promise of the eternal inheritance. This promise had been made to Abraham, long before the Law, and was quite independent of it, permanent not parenthetical, vi. 12-17. But whereas hitherto only the promise had been inherited, since the death of Christ the fulfilment also was available for all who were called. Such is the steady view of the epistle, xi. 39.

\section{THE COVENANT.}

Apart from these two verses, there is now no doubt that the main thread of argument is about not a Will, but a Contract; or rather about the Old Contract made at Sinai, and the New one promised through Jeremiah and arranged through Jesus, superseding the Old. The parties 
to the old contract were Israel and God, while Moses was the middle-man. For the new contract the middle-man is Jesus; the parties are not defined here, except by the quotation from .Jeremiah and by the vague phrase, "They who have been called;" it was not expedient to annoy Jews by obtruding the fact that all men were now free to contract with God; throughout the epistle the horizon is limited to Jews.

This subject of the Covenants bas been specially obscured by a Dutch theology which ignores the Bible usage of two historical contracts, at Sinai and at Calvary, and which dwells on two theological covenants "of works and of grace." To understand Hebrews these modern ideas must be banished from the mind. At Sinai the people promised to do what God asked, they heard His orders spoken direct or read by Moses from the Book of the Covenant, they held a solemn meeting and promised anew, they offered sacrifices to ratify the covenant, and they joined in the final meal before God. But within six weeks they broke one of the leading conditions, thus ending the covenant and absolving God from His promise; on the intercession of Moses He condescended to renew it. The next generation was equally faithless, but again it was renewed on the plains of Moab. Every succeeding geueration broke it, and after a solemn renewal in the days of Josiah and a wholesale apostasy under Jehoiakim, the prophets took up the thought of Hosea i. 9-11, and treated the covenant as broken beyond repair, so turned their hopes to a new one, Jeremiah xi., xxxi., xxxii., Ezekiel xvi., xxxvii., Isaiah xxiv., lxi. Ezra also felt that the old covenant was ended, and hoped he could be the middle-man of the new one, for which he elaborated a long service, Nehemiah ix. It does not seem to have occurred to him or to Josiah that while they were in earnest, they had no invitation from God to renew the covenant, and no token whatever that He paid any attention to their -proceedings. Later ages instinctively perceived this, and ignoring them, harked back to the transaction at Sinai, 
where undoubtedly God manifested His approbation, and took the initiative. But with strange blindness they fancied that though their side had never been kept, the contract was still in force, and that God was pledged to fulfill His side. With equal one-sidedness modern Jews still hold that this Covenant is available for them, though they explain away their obligation to fulfill half the conditions explicitly stated.

Really the New Corenant was announced by Jesus; the terms of this new contract were Love to God and Man, and the benefit offered was Pardon for sin and Help to do better. The ratifying service culminated at the cross, where the penalty of breach was borne by Jesus; and He ordered a festal meal in memory of the whole transaction. The new contract is open for any one to enter into on his own account; Jesus has arranged it and is surety that it will be carried out, surety for the Father to the contracting sinner, surety for the sinner to God. And whereas the Old Covenant had no promise, open or implied, that it could be begun again after failure, one of the leading features here is that when we fail to keep it, we may repent and confess to God, and find it still available.

TEE LAW.

From the Covenant we pass to the closely related topic of the Law. This is the Jewish Law, contained within the five books of Moses, especially in the three great collections, Exodus xx-xxiii., Leviticus with a few supplements in Numbers, Deuteronomy xii-xxvi. This Law is declared to be obsolete, and a variety of depreciatory terms are heaped upon it-changed, carnal, preliminary, annulled, weak, unprofitable, shadowy. Such amazingly strong language was necessary to drive into the patriotic heart of Jewish Christians that there was no sin in disregarding what was already repealed. If the great American Constitution with its history of 118 years was repealed from top to bottom, and no longer had any binding force, 
yet sentiment would cause millions to act voluntarily along its lines still. And if it should be highly inexpedient that such obedience should be given-may the profane supposition be forgiven-then the innovator would have to smite with sledge-hammer blows in order to break the links of custom.

There is however no explicit reference to the act of abrogation, nor any mention of a new Law substituted for the old. The matter had been implicitly settled when Peter publicly stigmatized the Law as "a yoke which neither our fathers nor we were able to bear," language unrebuked at Jerusalem, even by James. Those who acquiesced in such contempt had really conceded that the Law was done with. James had frankly admitted that whoever stumbles in a single point, keeping all the rest of the Law, was yet guilty of all; this is evidently a reductio ad absurdum, and he infers that the ancient Law is repealed and replaced by the Royal Law, Thou shalt love thy neighbor as thyself. No debate expressly on this point has been recorded, for in Acts xv. the point was whether the Law should bind Gentiles; but Paul's arguments to the Galatians, including many who were "Jews by nature and not sinners of the Gentiles," go nearly to the root of the matter. The Law was added till the Seed should come; now that faith is come, we are no longer under a tutor; Christ set us free from the yoke of bondage; the whole Law is fulfilled in one word; fulfill the law of Christ. While to the Romans he discussed chiefly the point of justification, yet he widened to say, Ye were made dead to the Law through the body of Christ, we have been discharged from the Law. If this may be understood of a few individuals exempt from the Law, which yet remains generally, he deals with it objectively to the Colossians, saying that Jesus blotted out the bond written in ordinances and took it out of the way, nailing it to the cross; and he goes on to drop a seed which finds here ample growth, that ceremonies are but shadows of a substance now come in Christ. 
Nailed to the cross. When Jesus declared with His dying breath, It is finished, He announced that the time had arrived at which He had hinted when He said that no jot nor tittle could pass from the Law "till all things be accomplished." Even then He had criticised isolated details of the Law, Thou shalt not kill, Thou shalt not commit adultery, Thou shalt not forswear thyself, An eye for an eye; in place of these He had offered one comprehensive and deeper precept, declaring that it was the Law, All things whatsoever ye would that men should do to you, even so do ye also unto them. And thus in one sense He filled the Law full; but in another sense His whole life was a fulfilling it, obeying it in every minute detail. If to John $\mathrm{He}$ said at the outset that He must fulfill all righteousness, He declared to the Father at the end that He had accomplished the work assigned Him, and the claim was admitted in the resurrection. Christ then had fulfilled the Law, and his death brought down the whole scaffolding with a crash, leaving instead His own permanent command, Love one another.

Now in this epistle the moral side of the Law is not touched, it is the temple ritual that is chiefly discussed; but it is urged that a change even in any detail of ritual really means a change of the whole Law. The position of James is endorsed, that the Law is one and indivisible. This was indeed the general Jewish view; Paul warned that obedience to the law of circumcision was useless unless the burden of the whole Law was assumed; Moses had bidden Israel neither add nor diminish. It may suit the modern Jew to classify the 613 precepts of the Law into four groups, and to say that the sacrificial laws are not binding because there is no temple, the political laws are not binding because there is no Jewish state, so that only the ceremonial and moral laws still hold; but no passage in the Law warrants this division and this putting half of it into obeyance. The Law stands or falls as a whole. And it fell, when Christ died.

This epistle deals directly with only one part of the 
subject, that the sacrificial laws are not binding on Jews; but the far wider conclusion is warranted, that no solitary part of the Law is now binding on any man whatever simply because it is part of the Jewish Law. Indeed this conclusion is drawn by others, and taught on the authority of Christ. Paul summed all the commandments in the word Jesus had quoted, Love thy neighbor as thyself, and said that love was the fulfillment of the Law. As a standard of conduct it has faded out of Peter's thought in his epistles, and he allegorizes in the strain of this epistle. Mark never mentioned the Law at all, in any part of his Gospel ; and he commented on our Lord's saying about clean and unclean, that it virtually made all meats clean. Luke the Gentile hardly mentions it except in reporting the speeches of others; if he mentions it on his own account it is usually with a significant qualification, such as, The Law of Moses. Matthew has preserved for us the two great utterances of our Lord, which concentrate and implicitly supersede it, vii. 12 , xxii. 40 . John even in his gospel seems equally detached, reports Jesus as calling it "your Law," contrasts it with the grace and truth that came through Jesus Christ; and in his epistles he never alludes to it; it is no rule of life to which he refers, it is not even a danger to be warned against, it is off his horizon, while the duty of a Christian is to keep Christ's commandments, summed up and repeatedly referred to in the phrase, Love one another.

It is astonishing that after this plain exposition by many writers, Christians often hanker after the Law, or after a few fragments of it. When we have a compact announcement of the will of Christ, the one Law-giver, who has all authority in heaven and on earth, how foolish to rake over the Jewish scrapheap and rescue a rusty chain or two to wear as a yoke of bondage! We live under the New Covenant, not the Old; our law is the will of Christ, not the Law of Moses. History attests that once men meddle with that obsolete rubbish, they are tempted to take up more and more of it, until in ritual they blossom out 
with rohed priests offering sacrifices on altars, in ceremonial they have holy days and celibacy and unclean food, in politics they have a doctrine of the infallibility of the Pope, and in ethics their "moral theology" stinks to high heaven. If many of us shudder at this as almost an apostasy from Christ, let us remember that he who appeals on any point whatever to the Law rather than to Jesus Christ, has in principle admitted all this declension, and when he himself presently feels inclined to stop will be powerless to draw any line.

\section{THE SACRIFICE OF CHRIST.}

When the Jewish law of sacrifice was criticised, the true meaning of sacrifice was set forth in the case of Jesus. First it was shown that the main purpose of the old animal sacrifices had been misunderstood. What ever the old heathen meant by sacrifice, whether a totem feast, a sacramental meal, a harvest festival, or what not, yet the main thing meant by God for the Jews was, a reminder of sin. Sin was the one thing dwelt on in sin-offering, trespass-offering, burnt-offering, atonementoffering. This was well known. But there was some novelty in saying that sacrifice served only to recall sin to unind, not to banish it and give an easy conscience. Even spiritual psalmists had not seen things quite in this light; they knew that God wanted broken and contrite hearts, but saw no connection with sacrifice, and were somewhat inclined to withhold it; while mere ritualist choirmasters editing the psalms for public worship, cheerfully acquiesced in the notion that to roast a bullock whole on the altar was itself good.

It was a splendid contribution to thought that sacrifices were to recall sin to mind and make the conscience uneasy. Missionaries still find the Christian application true, that when talking about duty will arouse no sense of sin, yet the story of Jesus dying on the cross can cause shame and repentance. 
Then came the next problem, how to get rid of sin; and the notion is brushed aside contemptuously that blood can do it. If this is to us axiomatic, to them it was revolutionary. An educated Hindu to-day thinks that he can get into communion with God by putting his limbs into a certain position and stroking his stomach; small wonder that educated Jews then still dallied with the thought that blood could cover up sin. This writer can hardly conceal his scorn of such materialist notions; and his insight is the more remarkable if he had not actually seen and smelt the steaming slaughterhouse of the temple, but simply read as we do the directions in Leviticus. According to the Law, nearly everything is cleansed with blood! Apart from shedding of blood there is no forgiveness! We must have better sacrifices than this.

What then does he rely on, the blood of Christ? Not so, if that phrase be taken literally. He uses it as a halfway house in his exposition; but he presently speaks also of the Body of Christ. And when he discards metaphor, he lays the stress on the Obedience of Christ. "Lo, I am come to do Thy will." This is comprehensible. Man's sin is dealt with by man, not by bulls and goats. Man's disobedience is met with man's obedience. These things are on a plane.

How far was this obedience carried? Through life to death, and we are not warranted in dissecting them apart and discarding either. Christ's life was one perpetual obedience, from birth under the Law to acquiescence in a condemnation for blasphemy at the lips of the high priest. He announced publicly that He came to fulfill the Law ; He bade the leper go and obey the rule as to purification. He openly challenged His foes whether they saw any fault in Him, and except for mutterings about the Sabbath, which He met by saying that He disregarded their traditions, there was no reply. The general people, a hostile council, an intimate like Judas, a dispassionate observer like Pilate, all concurred in seeing no fault. But a crucial test came in Gethsemane, to cease obeying; 
hard was the struggle, yet the issue was as usual, Thy will be done. And so He was obedient, even to death. The twelve legions of angels were not summoned, the sword of Peter was ordered back to its sheath, the taunt "Himself He cannot save" was allowed to pass; and $\mathrm{He}$ died on the cross. With that the sacrifice was complete, and instantly the veil of the temple was rent in twain in token that once again, as in the days of Ezekiel, the place was abandoned by God, and its secrets were exposed to all.

\section{THE PRIESTHOOD OF CHRIST.}

While the sacrifice is important, the Priest is the central topic here. There were priests before Aaron, the memory of them remained in the days of the Levitical priests, and a future priest of one such type was promised; in Jesus he appeared. Such is the argument.

But what is the most important duty of a priest? And from the analogy of the Day of Atonement the answer is, To enter the Holy of Holies after the sacrifices, and intercede for forgiveness. This was no novel doctrine; every priest, if physically unblemished, might butcher an animal, tend the fire, daub the blood; but to enter tho temple and burn incense was a far greater honor, only possible for a few, and so dealt out by lot, and permitted only once in a lifetime. And to enter the inner apartment was permitted to the high priest alone, on one day only in each year.

So from this analogy the chief priestly work of Jesus came after His sacrifice; and therefore it lies in heaven. When sacerdotal metaphor is dropped, we find it stated in such terms as these: To show mercy and bestow grace to help in time of need; to be the author of eternal salvation to all that obey Him; to be our forerunner in heaven; to lead us nigh to God; to save to the uttermost by making intercession; to cleanse our conscience from dead works; to serve the living God; to appear before the face of God for us; and, yet in the future, to appear before. 
us for God to complete our salvation by the abolition of sin and taking us into full fellowship. While then the initial atoning work of Jesus receives ample recognition, yet the emphasis is thrown on the continuous intercessory work to culminate in the Second Advent, when we too pass within the veil.

Christ's prophetic work is over; no longer does He teach in person, that was done once while He lived on earth; now we are His deputies to speak for Him and announce salvation. His kingly work is hardly begun, except where the few enthrone Him in their hearts; He is sitting and waiting till His foes be made His footstool, that He may take His great power and reign. But His priestly work is at its zenith. For all who accept Him as their representative, He is the ambassador at the court of heaven, presenting our praise and our prayer. He takes the initiative and pleads what He has wrought. Through Him passes upward our confession of sin, through Him pass downward forgiveness and cleansing and help. 